\title{
Evolution of seed dispersal in the Cerrado biome: ecological and phylogenetic considerations
}

\author{
Marcelo Kuhlmann ${ }^{1 \star}$ and José Felipe Ribeiro
}

Received: December 17, 2015

Accepted: March 31, 2016

\begin{abstract}
The investigation of the phylogeny of a group of organisms has the potential to identify ecological and evolutionary processes that have been occurring within a community. Seed dispersal is a key process in the life cycle of vegetation and reflects different reproductive strategies of plants to a set of ecological and evolutionary factors. Knowing the dispersal syndromes and fruits types of a plant community may help elucidate plant-animal interactions and colonization strategies of plants. We investigated dispersal syndromes and fruit types in Cerrado formations as a parameter for understanding the evolution of angiosperm reproductive strategies in this mega-diverse tropical biome. To do this we identified and mapped the distribution of different parameters associated with seed dispersal on a phylogeny of Cerrado angiosperms genera and tested the presence of phylogenetic signal. The results showed that there were strong relationships between fruit types, seed dispersal strategies and vegetation life forms and that these traits were closely related to angiosperms phylogeny and, together, contribute to the evolution of plants in the forest, savanna and grassland formations of the Cerrado biome.
\end{abstract}

Keywords: dispersal strategies, forest, fruit types, grassland, life forms, phylogeny, savanna

\section{Introduction}

The evolution of angiosperms started about 130 million years ago (Crane et al. 1995) and, to date, there is an extraordinary diversity of its fruits, with almost a hundred morphological types being described (Spujt 1994; Eriksson et al. 2000). The appearance of fruits was a remarkable innovation in the evolutionary history of plants, which contributed greatly to the increase in seed dispersal efficiency (Pijl 1982; Fleming \& Kress 2013). Understanding how the diversification of fruits and the different seed dispersal strategies are related with the phylogeny of plants of a biome is important to assess evolutionary mechanisms acting in this key process of the life cycle of vegetation (Howe
\& Smallwood 1982; Fleming 1991; Jordano et al. 2006).

Plant-animal interactions have had central role on the evolution and diversification of fruit morphology and seed dispersal in the life of angiosperms (Jordano 1995; Fleming \& Kress 2013). The changes in the structure of vegetation during the history of Earth, with the increase of forest ecosystems, allowed intense radiation of fruit types and shifts in seed dispersal patterns (Eriksson et al. 2000; Eriksson 2008). The dispersal modes associated with the strata of vegetation and the kinds of environments directly influence the dispersive capacity and geographic distribution of plant species (Fenner 1985; Lorts et al. 2008). By knowing the dispersal syndromes and the morphological patterns of the fruits of a plant community may help to elucidate

\footnotetext{
${ }^{1}$ Instituto de Ciências Biológicas, Universidade de Brasilia, Campus Universitário Darcy Ribeiro, Asa Norte, 70910-900, Brasília, DF, Brazil

${ }^{2}$ Embrapa Cerrados, BR 020 Km 18, 73310-970, Planaltina, DF, Brazil

* Corresponding author: biomakp@gmail.com
} 
various issues on plant-animal interactions and on different colonization strategies of plants in the environments (Howe \& Westley 1997; Galetti et al. 2006; Wiesbauer et al. 2008).

Communities are built from groups of species that share certain similarities, both ecological and phylogenetic (Blondel 2003; Cavender-Bares et al. 2009), and by grouping organisms with similar survival strategies allows to relate processes that have been playing in the evolutionary history of these groups (May \& Seger 1986; Metzger 2000). Grouping plants from a community into functional groups according to their dispersal syndromes can help to understand some of these processes, since the morphology of the dispersal units generally reflect different strategies of plants for dispersion by various means, in response to a set of ecological and evolutionary factors (Thomson et al. 2010; Fleming \& Kress 2013).

Since species are phylogenetically related, their morphological features are not fully independent, and can be measured statistically by calculating the "phylogenetic signal" (Revell et al. 2008). This signal can be defined as the tendency of closely related species to resemble each other more than with other species of the phylogeny at random (Blomberg et al. 2003; Losos 2008). When the phylogenetic relationship of a group of organisms of a community is known, it is possible to investigate questions, such as how strongly certain morphological and ecological characteristics are related to each other, and if they form niches or groups strongly linked throughout phylogeny (Mouquet et al. 2012; Münkemüller et al. 2012). The investigation of the phylogeny of a group of organisms, through how the conservatism of phylogenetic niche shapes the species composition of a region, has the potential to rebuild transitions in the set of organisms and identify factors driving these processes (Hawkins 2006; Pennington et al. 2006a; Crisp et al. 2009). However, it is still unknown the extent to which this trend of retaining certain morphological and ecological ancestry features has influenced the composition and diversification of species in mega-diverse biomes such as Cerrado (Simon et al. 2009).

Cerrado is a seasonal tropical ecosystem, occupying an area of over 2 million $\mathrm{km}^{2}$ in South America (Klink \& Machado 2005) and is one of the world's hotspots (Myers et al. 2000), with over 12,000 species of vascular plants and $40 \%$ of endemism (Mendonça et al. 2008). It is estimated that this biome originated 10 million years ago, with the diversification of lineages of plants coinciding with the expansion of savanna vegetation around the world (Pennington et al. 2006b; Simon et al. 2009). The Cerrado biome is a vegetation complex that has different phytophysiognomies, grouped into three main formations: forests, savannas and grasslands (Ribeiro \& Walter 2008). In each of these formations prevails flora species with different life forms, reproduction and growth strategies, and the distribution of the vegetation is conditioned by many environmental factors (Eiten 1994; Ratter et al. 1997), such as the depth of the groundwater, the types of soils (Haridasan 1994; Reatto et al. 2008) and frequency of fires (Coutinho 1990; Hoffmann 1996). However, little is known about the influence of different seed dispersal strategies in floristic constitution and evolution of the Cerrado formations.

Herein, we investigated the distribution of different dispersal syndromes and fruit types in the Cerrado formations, as a parameter to understand the evolution of angiosperm reproductive strategies in the biome. More specifically, we have identified and mapped the distribution of different parameters associated with seed dispersal along the phylogeny of the Cerrado angiosperms to test the presence of phylogenetic signal on these parameters. The following questions were asked: (i) What fruit types and dispersal syndromes are present in different strata and formations of the Cerrado biome? (ii) What is the distribution of the fruit types and dispersal syndromes between the Cerrado angiosperms? (iii) Are those parameters associated with seed dispersal strongly linked to angiosperms phylogeny or they are evolutionarily labile? We also discuss, based on literature, what ecological processes may have occurred during the evolution of different fruit types and seed dispersal strategies to help understand these mechanisms in the Cerrado biome.

\section{Materials and Methods}

\section{Study area}

To help us answer the questions we worked with the species of the Flora of Federal District, a region that has the most well-known and collected flora in the Cerrado (Cavalcanti \& Ramos 2001; Felfili et al. 2004), which is pretty representative of the formations and vegetation types (Walter 2001) and the species that characterize the biome (Pereira et al. 1993; Ramos 1995; Proença et al. 2001). The Federal District is located in the central area of the distribution of the Brazilian Cerrado (15 $30^{\prime}$ $16^{\circ} 03^{\prime} \mathrm{S}$ and $\left.47^{\circ} 18^{\prime}-48^{\circ} 17^{\prime} \mathrm{W}\right)$, with an area of $5,810 \mathrm{~km}^{2}$ and average altitude of $1,100 \mathrm{~m}$ (Fig. 1). The region has a seasonal tropical climate, with wet (October-March) and dry (April-September) seasons, and the mean tempeture varies between $12^{\circ} \mathrm{C}$ and $29^{\circ} \mathrm{C}$ (Silva et al. 2008).

\section{Species classification}

To get an overview of seed dispersal in the Cerrado, all angiosperm genera $(1,500)$ of the biome were organized according to their syndromes, which were classified according to their primary morphological traits in three types: zoochory, anemochory and autochory (Fig. 2). To get more specific data, we worked with the better known flora of the Cerrado region, the Federal District flora. The updated lists of Cerrado genera and the species of this regional flora 


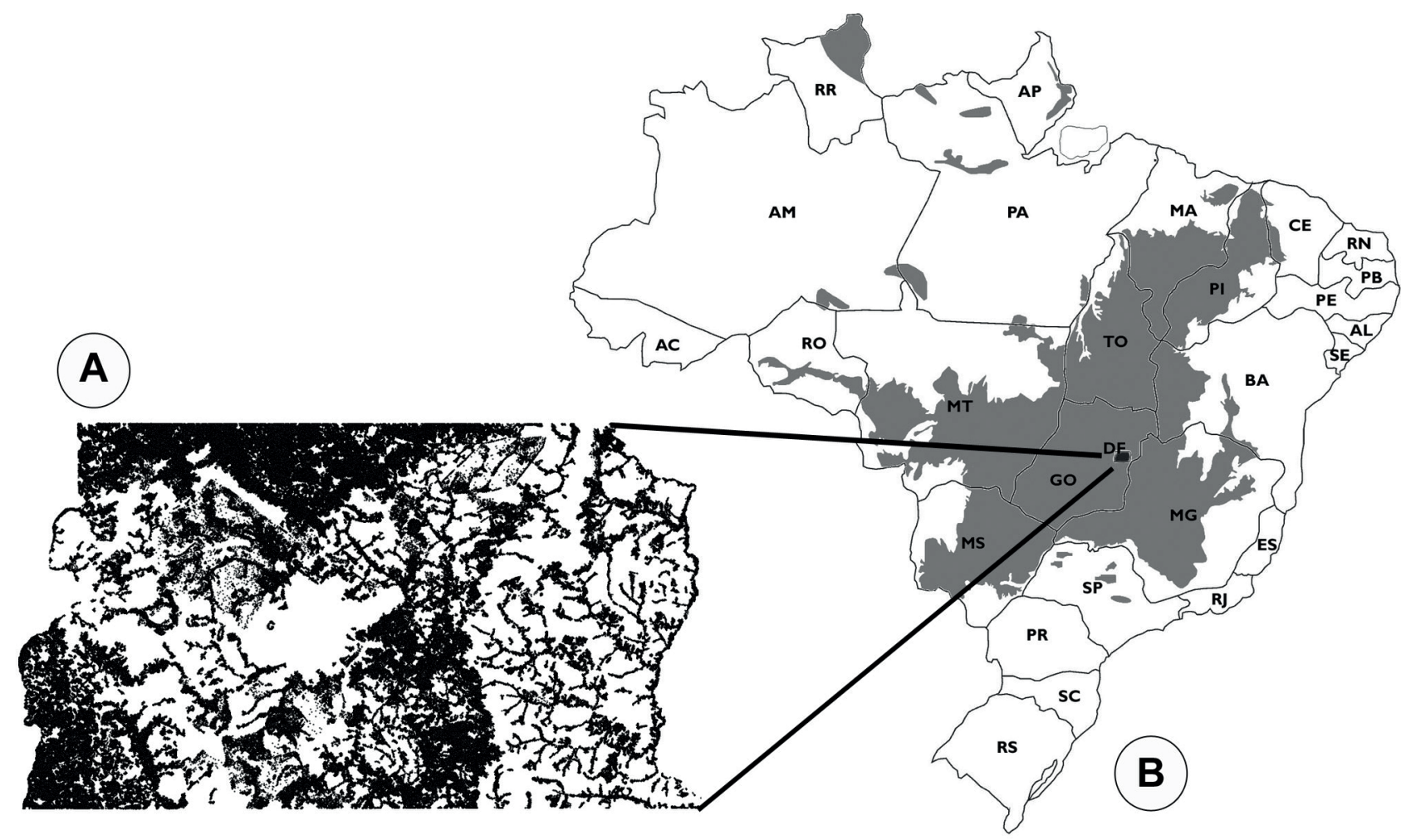

Figure 1. Map of Federal District (A) and Cerrado biome (B) (Source: Sano (2013) (A) and Ribeiro \& Walter (2008) (B)).

of the Federal District were obtained on the Flora of Brazil website (Forzza et al. 2015), where 3,200 native plant species were found, distribuited in 900 genera, 150 families and 43 orders (APG III 2009), corresponding to almost $30 \%$ of species, $60 \%$ of the genera and, most importantly, $85 \%$ of families described for the entire biome. The 3,200 plant species of Federal District flora were classified according to fruit types (as described in Barroso et al. 1999), dispersal syndromes (Howe \& Smallwood 1982), life forms (Mendonça et al. 2008) and vegetation formations of Cerrado (forest, savanna and grassland) (Ribeiro \& Walter 2008). Life forms were grouped in four strata: trees, shrubs, herbs and "vines", in which we put together plants that "grow over other plants" such as lianas, epiphytes and mistletoes, to facilitate analysis (Fenner 1985; Lorts et al. 2008). Fruit types were grouped in eight major types: capsule (dry, dehiscent), follicle (dry, dehiscent, unicarpelar), achene (dry, indehiscent), samara (dry, winged), berry (fleshy, without stone), drupe (fleshy, with stone), schizocarp (dry, segregating into smaller units) and artrocarp (dry, unicarpelar, segregating into smaller units) (Fig. 2).

\section{Data analysis}

To compare the proportions and relationships among the measured variables (fruit types, dispersal syndromes, life forms, vegetation formations) between the 3,200 species from the studied area, we used the G-test, using the package
"DescTools" on R program and a significance level of 5\%. This test was suitable for comparing the proportions and served to verify if the observed differences between the analysed variables were significant or not (McDonald 2014).

To measure and test if the parameters associated with seed dispersal (syndromes, fruit types, fruit traits, life forms) had phylogenetic signal we used the "lambda" method (Pagel 1999), with the statistical package "phytools" (Revell 2012) on R program (version 3.2.1). This method is based on maximum likelihood tests, considering the length of the branches of a phylogenetic tree to calculate the phylogenetic signal of categorical traits, and generates a value of "lambda" ranging on a scale from " 0 " to " 1 ", where "0" corresponds to absence of phylogenetic signal and " 1 " maximum phylogenetic signal of the parameters (Münkemüller et al. 2012). For this test, it was first necessary to construct a phylogenetic tree for the angiosperm genera of the Cerrado. This tree was constructed using the MEGA program (version 6.0.6), with molecular sequences data obtained on the GenBank (2015) website, where we found data for 605 of the 900 genera of Federal District flora. The chloroplast DNA nucleotides used were "rbcl" and "matk", because they are quite frequent in GenBank for angiosperms. This tree was constructed using Maximum Likelihood analysis and testing of the "bootstrap" with 1000 replications and, from there, generated a tree in the format "newick" which was used in the R program to test the phylogenetic signal of the parameters associated with seed dispersal. 

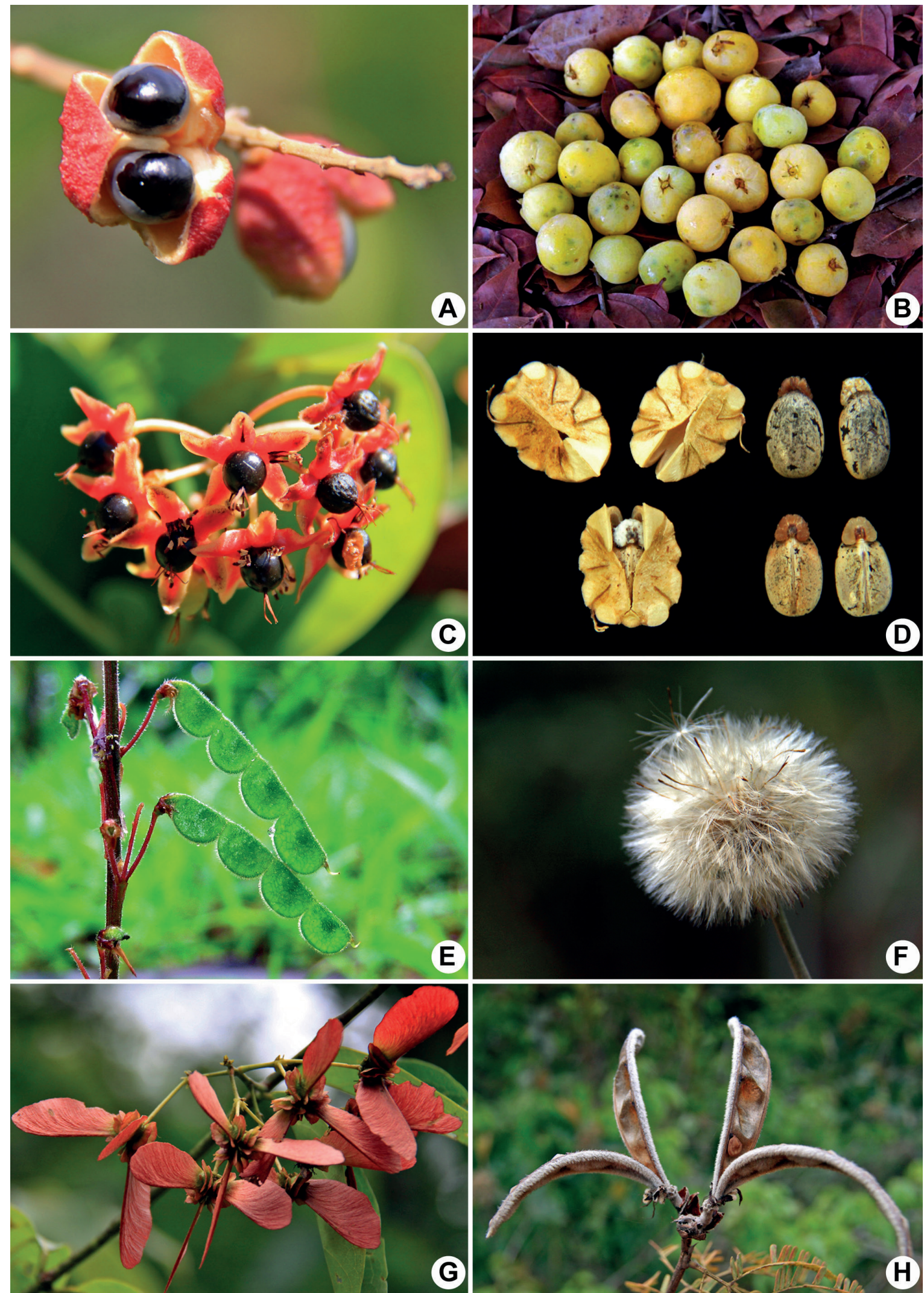

Figure 2. Examples of Cerrado fruits and syndromes. Zoochory: (A) capsule, with arylated seeds (Matayba guianensis); (B) berry (Eugenia dysenterica); (C) drupe (Byrsonima umbellata); (D) schizocarp, with elaiosome (Manihot violacea); (E) artrocarp, epizoochory (Desmodium sp.). Anemochory: (F) achene (Asteraceae); (G) samara (Diplopterys pubipetala). Autochory: (H) follicle (Calliandra dysantha) (photos: Marcelo Kuhlmann). 


\section{Results}

From the 3,200 native species of Cerrado analyzed, we found that most of them were herbs (53\%), followed by trees (17\%), shrubs (16\%) and "vines" (14\%). Many species occurred in more than one formation, being $58 \%$ in forests, $40 \%$ in savannas and $56 \%$ in grasslands. These proportions are similar to those found for the entire biome (Mendonça et al. 2008), confirming the good representation of the flora analyzed. The proportion of taxa between the dispersal syndromes was quite similar, featuring a 1: 1: 1 ratio to zoochory, anemochory and autochory, both for the 3,200 species and for the 1,500 genus analyzed of the Cerrado biome.

Concerning the eight types of fruit in the studied area, capsule was the most common (36\%), followed by achene (25\%), berry (11\%), drupe (9\%), follicle (6\%), artrocarp (5\%), schizocarp (5\%) and samara (4\%). The dispersal syndromes differed significantly according to the proportion of fruit types $(G=2531, P<0.0001)$. Zoochory showed greater variation in types of fruits, appearing in seven of the eight categories. "Dry fruits" together (excluding berry and drupe) represented $80 \%$ of the species and genera also of the flora analysed. Several traits were found in fruits related to each of the syndromes and some families were more strongly linked to each syndrome based on their number and proportion of species and genera (Tab. 1).

The proportion and number of species of each dispersal syndrome in the studied area varied significantly between the vegetation formations ( $G=187, P<0.0001)$ and between life forms of vegetation $(G=847, P<0.0001)$. Forests had higher proportion of zoochory (43\%), while autochory predominated on savannas (39\%) and grasslands (44\%). Among the life forms, tree and shrub (woody) had higher proportion of zoochory ( $71 \%$ and $50 \%$ resp.), herbs had the highest proportion of autochory (50\%) and among "vines" anemochory predominated (58\%). Relating the

Table 1. Fruit types, traits, and most representative families for each dispersal syndrome for 3,200 species and 150 families of the Cerrado. The number of species is between parentheses.

\begin{tabular}{|c|c|c|c|}
\hline Syndromes & Fruit types & Fruit traits & Most representative families \\
\hline $\begin{array}{l}\text { Zoochory } \\
(1080 \mathrm{spp})\end{array}$ & $\begin{array}{c}\text { berry (355) } \\
\text { drupe (273) } \\
\text { achene (184) } \\
\text { capsule (129) } \\
\text { schizocarp (54) } \\
\text { artrocarp (44) } \\
\text { follicle (41) }\end{array}$ & $\begin{array}{c}\text { fleshy (628) } \\
\text { adherent (135) } \\
\text { elaiosome (117) } \\
\text { aril (113) } \\
\text { pseudo fruit (36) } \\
\text { resin (26) } \\
\text { mimetic seed (25) }\end{array}$ & $\begin{array}{c}\text { Rubiaceae (79) } \\
\text { Myrtaceae (75) } \\
\text { Euphorbiaceae (49) } \\
\text { Solanaceae (35) } \\
\text { Lauraceae (24) } \\
\text { Moraceae (19) } \\
\text { Annonaceae (17) } \\
\text { Araceae (16) } \\
\text { Loranthaceae (16) } \\
\text { Arecaceae (14) }\end{array}$ \\
\hline $\begin{array}{l}\text { Anemochory } \\
(1032 \mathrm{spp})\end{array}$ & $\begin{array}{c}\text { capsule (577) } \\
\text { achene (328) } \\
\text { samara (115) } \\
\text { schizocarp (7) } \\
\text { follicle (5) }\end{array}$ & $\begin{array}{c}\text { plumes }(412) \\
\text { winged (343) } \\
\text { lightness }(277)\end{array}$ & $\begin{array}{c}\text { Asteraceae (290) } \\
\text { Orchidaceae (250) } \\
\text { Apocynaceae (91) } \\
\text { Bignoniaceae (84) } \\
\text { Malpighiaceae (70) } \\
\text { Dioscoreaceae (27) } \\
\text { Bromeliaceae (22) } \\
\text { Eriocaulaceae (19) } \\
\text { Vochysiaceae (14) } \\
\text { Aristolochiaceae (8) }\end{array}$ \\
\hline $\begin{array}{l}\text { Autochory } \\
(1088 \mathrm{spp})\end{array}$ & $\begin{array}{c}\text { capsule (436) } \\
\text { achene (293) } \\
\text { follicle (160) } \\
\text { artrocarp (112) } \\
\text { schizocarp (87) }\end{array}$ & $\begin{array}{l}\text { "not evident" (928) } \\
\text { explosive fruits }(160)\end{array}$ & $\begin{array}{c}\text { Fabaceae (209) } \\
\text { Cyperaceae (121) } \\
\text { Convolvulaceae (69) } \\
\text { Lamiaceae (65) } \\
\text { Melastomataceae (33) } \\
\text { Malvaceae (32) } \\
\text { Acanthaceae (30) } \\
\text { Verbenaceae (25) } \\
\text { Amaranthaceae (23) } \\
\text { Gentianaceae (18) }\end{array}$ \\
\hline
\end{tabular}


three variables together (dispersal syndrome, life form and vegetation formation), it was observed that the syndromes showed similar ratios among the three formations in all four strata of vegetation (Fig. 3). Regardless of the Cerrado formations, zoochory was always more associated with the woody strata (tree and shrub), while autochory was more associated with herbs and anemochory showed higher proportion related to "vines".

The types of fruits and dispersal syndromes of the studied species differed significantly in the proportion of families in which they occurred within the five major lineages of angiosperms $(G=182, P<0.0001$ and $G=66$, $P<0.0001$ resp.). With monocots only four types of fruits were found (capsule, drupe, berry, achene) and only among the rosids did all eight kinds of fruits occur. Capsule was presented in 80 families (53\%) and the artrocarps in only two (1\%) (Fabaceae e Lamiaceae). Dry fruits occurred in 125 families (83\%) and flesh fruits in 81 families (55\%). Zoochory was presented in 100 of the 150 families (67\%), autochory in $62(41 \%)$ and anemochory in 41 (27\%). Of the total families, 110 were associated exclusively to only one of the syndromes, while in the other 40 there was more than one dispersal mode. Zoochory was the one with the largest number of exclusive families (63), followed by autochory (34) and anemochory (13) (Fig. 4).

The test for phylogenetic signal resulted in a significant and high value of "lambda" (close to 1 ) for all parameters associated with the dispersal strategies (Tab. 2). This indicates that these parameters are strongly associated with the phylogeny of angiosperms. Mapping the chosen parameters in the Cerrado angiosperms phylogeny, at a genus level, indicated a phylogenetic signal, showing that the dispersal syndromes were distributed non-randomly in the phylogenetic tree, forming well defined phylogenetic

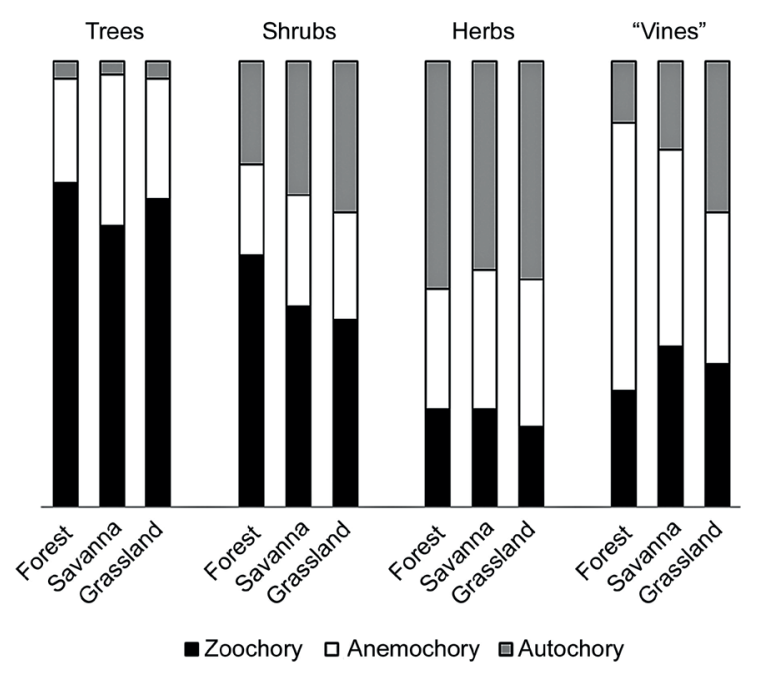

Figure 3. Comparison of the dispersal syndromes among different life forms in forest, savanna and grassland for 3,200 species of the Cerrado. niches between the branches of the phylogeny (Fig. 5). The distribution of the other parameters analyzed (fruit type, fruit dry/fleshy, fruit traits and life forms) should show similar patterns, forming well defined niches throughout the phylogeny.

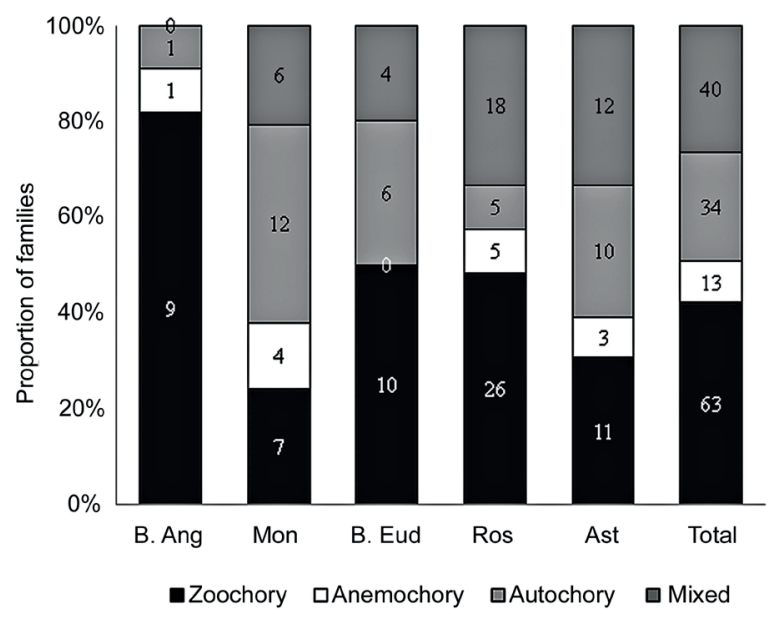

Figure 4. Proportions in a sample of 150 Cerrado angiosperms families that have each dispersal syndrome in major lineages of angiosperms: $B$ Ang = basal angiosperm, Mon = monocots, $B$ Eud $=$ basal eudicots, Ros $=$ rosids, Ast $=$ Asterids. Mixed families have more than one dispersal syndrome. Number of families is indicated.

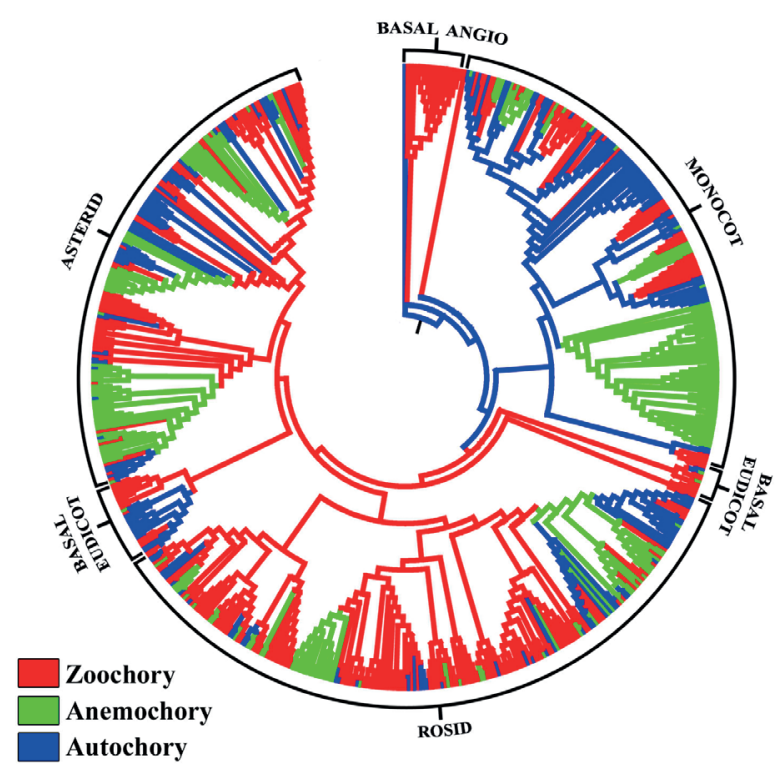

Figure 5. Phylogenetic structure and mapping of dispersal syndromes for Cerrado angiosperms genera (605 genera, 141 families), grouped in major lineages: Basal angiosperms, Monocots, Basal eudicots, Rosids and Asterids. This phylogeny is in agreement with APG III (2009). Please see the PDF version for color reference. 
Table 2. Phylogenetic signal values for different parameters related to seed dispersal among Cerrado angiosperms.

\begin{tabular}{|l|c|c|}
\hline Parameter & Phylogenetic signal (“lambda”) & P-value \\
\hline Dispersal syndrome & 0.892 & $<0.0001$ \\
\hline Fruit type & 0.925 & $<0.0001$ \\
\hline Fruit dry/flesh & 0.933 & $<0.0001$ \\
\hline Fruit traits & 0.909 & $<0.0001$ \\
\hline Life form & 0.937 & $<0.0001$ \\
\hline
\end{tabular}

\section{Discussion}

\section{Ecology and evolution of seed dispersal in the Cerrado biome}

Dry fruits, especially capsule and achene, predominated among the species analyzed in the studied areas of Cerrado, while there was no predominance of any particular type of seed dispersal among the analysed flora or for Cerrado genera, suggesting that the three syndromes (zoochory, anemochory, autochory) are probably equally distributed (1:1:1) among all plants of the biome. However, as Cerrado is a mosaic of vegetation, these characteristics differed mostly between particular formations, with the highest proportion of zoochory in forests and larger proportions of abiotic syndromes in more open formations. It was also observed that the different syndromes were significantly linked to the life forms of vegetation and, indeed, there is a positive relationship widely accepted in the literature for the combination between fleshy fruits $\mathrm{X}$ zoochory $\mathrm{X}$ woody plants $\mathrm{X}$ forests, and between dry fruits $\mathrm{X}$ abiotic syndromes $\mathrm{X}$ herbaceous plants $\mathrm{X}$ open environments (Fleming et al. 1987; Willson et al. 1990; Tiffney \& Mazer 1995; Bolmgren \& Eriksson 2005; Moles \& Westoby 2006). Biotic and abiotic factors contribute to determine the ability of plants to disperse seeds and, therefore, act as selection factors on this stage in their life cycle (Fleming \& Kress 2013). Such factors include: availability of dispersal agents in the environment (wind, animals), vegetation structure, availability of favorable sites for establishment, number of seeds produced, seed size and the morphology of diaspores with their various attributes to promote transport from the parent plant (Willson 1993; Eriksson \& Jakobsson 1999).

As one-third of the species and genera analyzed for the Cerrado presented traits related to seed dispersal by animals, the importance of fauna in evolutionary history and constitution of much of the biome vegetation is relevant, mainly between woody species and forest formations. Zoochory was the syndrome with greater variety of fruit types in the studied area, including, in addition to berries and drupes, dry fruits with various traits such as aril, elaiosome, pseudo fruits and also hooks and spines that can adhere to mammal fur or bird plumage, related to epizoochory. About $10 \%$ of the analysed zoochoric fruits had traits related to epizoochory and almost all of them were herbs that occur in grasslands, which enhances efficiency of this dispersal strategy in this environment, where ground animals move primarily horizontally (Gottsberger \& Silberbauer-Gottsberger 2006). Fruits with fleshy tissues evolved many times and independently during the history of plants (Bolmgren \& Eriksson 2010; Fleming \& Kress 2013) and several hypotheses have been raised to explain this. First, fleshy fruits attracted frugivore animals that fed pulp and contributed to seed dispersal and also this pulp could contain substances capable of decreasing the retention time in animal intestines, reducing the harmful effects of frugivory (Herrera 1989; Cipollini \& Levey 1997). The evolution of fleshy fruits was also associated consistently with the increase in seed mass (Leishman et al. 2000) and selective pressures have favored larger and thicker seeds, because they would be more resistant to mechanical and chemical abrasion of the digestive tract of animals (Bolmgren \& Eriksson 2010). In addition, larger seeds have larger reserves of nutrients that allowed them to establish better in dense vegetation and low-light environments, home to most of the fruit eaters (Leishman et al. 2000; Tiffney 2004). Thus, the appearance of fleshy fruits would have favored the dispersion of large seeds, which require biotic means to transport greater distances for establishing outside the intermediation of the parent plant (Janzen 1969; Eriksson et al. 2000; Eriksson 2008). Frugivores of different sizes also would have played an important role in the selection of zoochorous fruits, since there is a positive relationship between the size of the diaspore and the size of the animal that is capable of removing the fruit (Jordano 2000; Galetti et al. 2013). In geological time, abiotic dispersal modes predominate during the Cretaceous period (130 Ma) between gymnosperms and angiosperms (Tiffney 1984), but with the extinction of dinosaurs and climate change at the beginning of the Tertiary period $(65 \mathrm{Ma})$ there was greater development of forest systems with more dense vegetation, which was accompanied by greater abundance and diversity of zoochorous fruits and fruit-eating animals, especially birds and mammals (Bolmgren \& Eriksson 2005). Finally, these hypotheses seem to describe plausible ecological processes to explain the evolution of zoochory in tropical biomes and also in Cerrado.

Wind dispersed species have diaspores of different sizes and extraordinary aerodynamic shapes that help them 
float to be transported far away from the parent plant (Pijl 1982). Among the anemochoric plants of Cerrado studied here, traits like plums, winged diaspores and lightness (tiny seeds as Orchidaceae) predominate. The fruit types that were more associated with wind dispersal were capsule, achene and samara (which was exclusively anemochorous). To understand the evolution of wind dispersal, some models have been proposed based on physical factors that affect the aerodynamic ability of diaspores, such as wind speed and direction and height of release (Okubo \& Levin 1989; Levin et al. 2003). Different diaspores formats respond unequally to these factors, which act as selective pressures in the anemochorous fruits and seeds, since they influence the distance they are transported (Levin et al. 2003). The development of smaller and lighter seeds also favored the selection of anemochoric plants by providing greater productivity, and the environment where the individual lives is another important factor to be taken into account, since wind dispersal of the same plant species will be drastically affected if it is in a cleared area or in a dense forest (Eriksson \& Jakobsson 1999). As found for the species analysed in Cerrado, anemochory showed similar proportions in all formations, being slightly higher in savanna and grasslands than it was in the forests, for trees, shrubs and herbaceous species. However, there was strong relationship of this syndrome with the "vines" strata (almost $60 \%$ of anemochory), which included plants growing over other plants such as lianas (many Apocynaceae and Bignoniaceae) and epiphytes (many Orchidaceae). These plants grow seeking for light and greater exposure to wind effect, especially in the canopy of trees in forests, indicating important strategic role of this life forms in the evolution of anemochoric plants. Although we included among "vines" plants like mistletoes, which are predominantly zoochorous, they represented less than $10 \%$ of this strata in the studied area, and this also could reinforce the predominance of anemochory among the plants that "grow over other plants".

For autochory dry fruits such as capsule, follicule and achene predominated and schizocarps and artocarps also had higher proportions in this syndrome. Autochory was also strongly associated with herbs, which presented almost $80 \%$ of autochory in the studied area. Among the special traits for this dispersal strategy, elastic or explosive dehiscence characterized active autochory, which is favored in hot, dry periods (Gottsberger \& Silberbauer-Gottsberger 2006). This trait would have evolved from the improvement of dehiscence of the pericarp tissue of some fruits (greater torsion and pressure), allowing the expulsion of seeds at longer distances (Barroso et al. 1999). But curiously, the "no evidence" of any traits associated with seed dispersal was the one that was more present in autochorous diaspores, and also accounted for almost a third of all species analyzed in this study in Cerrado. Willson et al. (1990) found that between 20 and $50 \%$ of regional floras in different parts of the world did not have special features for seed dispersal, and some explanations for this phenomenon have been raised. Possibly these diaspores are associated with secondary forms of dispersal and not directly related to their morphology, and thus required occasional dispersal agents such as rainwater or grazing animals that swallow the seeds when feeding (Vargas et al. 2012). An additional explanation for the large number of taxa without obvious attributes to seed dispersal (mainly herbaceous species) is that these special features require higher energy costs, which could reduce plant fertility (Eriksson \& Jakobsson 1999). In herbaceous plants, the cost-benefit ratio between production of many small seeds versus a few large seeds (which would require special appendages to dispersal, like wings or fleshy tissues) seems to have been favored by natural selection by opting for higher fertility and productivity instead appendices for dispersal (Eriksson \& Jakobsson 1999). More open environments, such as savannas and grasslands of Cerrado, where herbaceous species prevail, also favor lower energy cost dispersal modes like passive autochory, so that large seeds would have greater importance in denser and shady environments, like forests (Westoby et al. 1996). Thus, the lack of special features to seed dispersal itself would be the selected trait on these species to increase dispersal efficiency, which would respond in favor of improved productivity, being as important for seed dispersal as any morphological structure designed for this.

The results showed that there seems to be strong evolutionary relationship between life forms and dispersal strategies in flowering plants such as woody plants $\mathrm{X}$ zoochory, "vines" $\mathrm{X}$ anemochory and herbaceous plants $\mathrm{X}$ autochory, and the differences observed between the vegetation formations of Cerrado seem to reflect the life forms of vegetation that predominate in each environment. In addition, this can be also confirmed if analyzing phytosociological studies in Cerrado (Pinheiro \& Ribeiro 2001; Fonseca \& Silva Junior 2004; Fontes \& Walter 2011), in which was observed that areas with low floristic similarity between them, but with the same structure of vegetation, were quite similar in terms of dispersal strategies, both for the number of species and the number of individuals of each syndrome. Thus, it is expected that even distant communities with high floristic differences may be quite similar for functional ecological processes, as in the case of dispersal strategies, since they are similar regarding the structure of the vegetation (May \& Seger 1986).

For the Cerrado biome, another possible selective pressure that can be highlighted to understand the evolution of seed dispersal in this biome is the seasonal climate (with dry and rainy season). It has been demonstrated that anemo and autochorous species produce fruits mainly in the dry season, since this period provides favorable conditions for the drying process and fruit dehiscence to release the seeds, while zoochorous species generally produce fruits during the rainy season, when fleshy fruits can keep attractive for longer time. On the other hand, dry zoochorous fruits, 
such as in Copaifera and Hymenaea, tend to produce fruits during the dry season (Batalha \& Mantovani 2000; Batalha \& Martins 2004; Gottsberger \& Silberbauer-Gottsberger 2006). As a vegetation that is susceptible and conditioned by fire (Coutinho 1990), especially savannas and grasslands, this is another factor that can play selective pressure on fruit types in Cerrado. It has been demonstrated that fire increases nutrient cycling on soil and stimulates flowering and thus seed production in some Cerrado plants, such as Poaceae, Cyperaceae and Bromeliaceae (Munhoz \& Felfili 2007), and that high temperatures caused by fire can also accelerate fruit drying and seed release and higher germinability in some species, like Kielmeyera coriacea, which have a coriaceous dry fruit (Cirne \& Miranda 2008; Zaidan $\&$ Carreira 2008). However, there is still little information available about the fire effects on fruit production and germination of the Cerrado species, especially in woody plants (Palermo \& Miranda 2012).

\section{Phylogenetic signal of seed dispersal parameters}

As plants have diversified throughout evolutionary history they colonize wide variety of environments and developed different life forms and seed dispersal strategies (Tiffney 1984; Eriksson et al. 2000; Moles et al. 2004; 2005). The tests in this study showed that fruit types, seed dispersal strategies and life forms of vegetation had high value of phylogenetic signal, indicating that these parameters are strongly linked to the phylogeny of Cerrado angiosperms at a genus level. Since species with genetic proximity tend to be ecologically similar (Darwin 1859; Derrickson \& Ricklefs 1988), analyses of phylogenetic signal can serve to assess the extent to which phylogeny explains similarities or differences between organisms (Harvey \& Pagel 1991; Münkemüller et al. 2012).

The mapping of parameters associated with seed dispersal (syndromes, fruit types and life forms) in the phylogenetic tree also enabled to visualize the formation of some phylogenetic niches, indicating that these parameters were not randomly distributed in the phylogeny and were more closely related to some taxa than others. For example, among the basal angiosperms predominated fleshy fruits and zoochory, represented mainly between Laurales and Magnoliales, and anemochory and winged seeds being present only in Aristolochiaceae. In monocots, composed mostly of herbaceous plants, capsular fruits and autochory predominated, but some orders and families showed a greater association with other syndromes, such as Orchidaceae with anemochory and Alismatales, Arecales and Zingiberales with zoochory. Between basal eudicots zoochory was remarkable in Cactaceae, Dilleniales and Santalales. Between rosids zoochory was highlighted in Myrtaceae, Cucurbitaceae, Rosales, Sapindales and Malpighiales, except the Malpighiaceae family, where anemochory and samara fruits dominated. And between asterids, phylogenetic niches for anemochory in the families Asteraceae, Apocynaceae and Bignoniaceae (which are rich in liana species), niches for zoochory in Ericales and Rubiaceae and niches for autochory in several families of herbaceous plants of the Lamiales order were observed.

Ecological parameters, such as plant dispersal strategies, combined with phylogenetic and statistic inferences of the taxa involved, consist of powerful tools for understanding evolutionary patterns and processes in a community (Pagel 1999). However, some authors recommend certain care regarding the use of phylogenies in biological studies to assess evolutionary phenomenon (Losos 2008), since the phylogeny itself could not be interpreted as a causal mechanism of the current phenotype of living beings, but only as the pattern, reflection or effect of their evolutionary history, and would serve to raise hypotheses about the mechanisms that generated this pattern (Losos 2011). In contrast, some authors consider that phylogenetic patterns in a community can also be caused by the existing niche conservatism among similar taxa (Wiens et al. 2010). Once species and clades tend to retain their niches and ancestral features, characterizing the niche conservatism (Harvey \& Pagel 1991), the observation that certain ecological traits in a community are phylogenetically conserved could be interpreted both as a pattern of ecological similarity over time and as a process that helped to create this pattern in evolutionary history (Wiens et al. 2010). The presence of niche conservatism may also suggest that some ecological processes are more plausible than others, helping even to predict changes in response to environmental changes, such as climate change or species extinctions, that can cause population fragmentation in closely related clades (Knapp et al. 2008; Helmus et al. 2010).

\section{Final considerations}

Habitat changes occur faster than species can adapt to these changes and, currently, the destruction of natural ecosystems has been considered the greatest threat to biodiversity (Dirzo \& Raven 2003; Holt \& Gomulkiewicz 2004). Models of occupation and land use in Cerrado have led to loss of more than $50 \%$ of the original vegetation of the biome (Sano et al. 2008), bringing consequences such as soil degradation, increased invasive species and compromising the water cycles (Klink \& Machado 2005), with the deforestation of Cerrado even affecting rainfall patterns and increasing the duration of the dry season in Amazon regions (Costa \& Pires 2010). The observation that biomes are phylogenetically conserved (Crisp et al. 2009) also implies that its evolutionary potential could be seriously compromised by environmental changes, so that ecological processes such as seed dispersal, which have strong links with the angiosperms phylogeny, could be dramatically affected by the decline in biodiversity, with whole clades being affected, not just species in particular, 
causing a break in the phylogeny of plants. With this in mind, and knowing the ecological requirements for the persistence of the species in a phylogenetic perspective, it is possible to predict which changes in habitat a species or clade can tolerate based on those requirements that were important to their development during evolution (Wiens et al. 2010), and this could assist recovery programs of degraded areas like that found in the Cerrado.

These considerations indicate that the environmental conditions today can have very ancient roots, and the study of phylogeny is important to understand the evolution and distribution of morphological and ecological traits among taxa, but alone it does not identify all the processes that generated such phylogenetic patterns. Cerrado has a vegetation of great antiquity and presents various climatic and soil peculiarities that determine the distribution of its flora, with a wide range of ecological processes to be investigated phylogenetically to better understand the evolution of this mega-diverse biome. Here we evaluated the seed dispersal process from an ecological and phylogenetic point of view, and found that traits such as dispersal syndromes, fruit types and life forms were closely related to each other and with phylogeny, contributing together to the evolution and survival of angiosperms and influencing the biodiversity in the forest, savanna and grassland formations of the biome.

\section{Acknowledgements}

We thank the University of Brasilia Botany Pos Graduation Program and Embrapa Cerrados for logistical support; CAPES for the scholarship of the first author; Thais Nogales, Micheline Carvalho and Paulo Camara for assistance on the construction of the phylogenetic tree; Cassia Munhoz, Carolyn Proença and Bruno Walter for valuable suggestions on this work; and Christopher Fagg for reviewing the language of this manuscript.

\section{References}

APG - Angiosperm Phylogeny Group III. 2009. An update of the Angiosperm Phylogeny Group classification for the orders and families of flowering plants: APG III. Botanical Journal of the Linnean Society 161: 105-121.

Barroso GM, Morim MP, Peixoto AL, Ichaso CLF. 1999. Frutos e sementes morfologia aplicada à sistemática de dicotiledôneas. Viçosa, Editora UFV.

Batalha MA, Mantovani W. 2000. Reproductive phenological patterns of cerrado plant species at the Pé-de-Gigante Reserve (Santa Rita do Passa Quatro, SP, Brazil): a comparison between the herbaceous and woody floras. Revista Brasileira de Biologia 60: 129-145.

Batalha MA, Martins FR. 2004. Reproductive phenology of the cerrado plant community in Emas National Park (central Brazil). Australian Journal of Botany 52: 149-161.

Blomberg SP, Garland JRT, Ives AR. 2003. Testing for phylogenetic signal in comparative data: behavioral traits are more labile. Evolution 57: 717-745.

Blondel J. 2003. Guilds or Functional Groups: Does It Matter? Oikos 100: 223-231.

Bolmgren K, Eriksson O. 2005. Fleshy fruits-origins, niche shifts, and diversification. Oikos 109: 255-272.
Bolmgren K, Eriksson O. 2010. Seed mass and the evolution of fleshy fruits in angiosperms. Oikos 119: 707-718.

Cavalcanti TB, Ramos AE. 2001. Flora do Distrito Federal, Brasil. Vol. I. Brasília, Embrapa Recursos Genéticos e Biotecnologia.

Cavender-Bares J, Kozak KH, Fine PV, Kembel SW. 2009. The merging of community ecology and phylogenetic biology. Ecology Letters 12: 693-715.

Cipollini ML, Levey DJ. 1997. Secondary metabolites of fleshy vertebrate-dispersed fruits: adaptive hypotheses and implications for seed dispersal. The American Naturalist 150: 346-372.

Cirne P, Miranda HS. 2008. Effects of prescribed fires on the survival and release of seeds of Kielmeyera coriacea (Spr.) Mart. (Clusiaceae) in savannas of Central Brazil. Brazilian Journal of Plant Physiology 20: 197-204.

Costa MH, Pires GF. 2010. Effects of Amazon and Central Brazil deforestation scenarios on the duration of the dry season in the arc of deforestation. International Journal of Climatology 30: 1970-1979.

Coutinho LM. 1990. Fire in the ecology of the Brazilian Cerrado. In: Goldammer JG. (ed.) Fire in the tropical biota. Ecological Studies, 84. Berlin, Springer Verlag. p. 82-105.

Crane PR, Friis EM, Pedersen KR. 1995. The origin and early diversification of angiosperms. Nature (London) 374: 27-33.

Crisp MD, Arroyo MT, Cook LG, et al. 2009. Phylogenetic biome conservatism on a global scale. Nature 458: 754-756.

Darwin C. 1859. On the origin of species. London, John Murray.

Derrickson EM, Ricklefs RE. 1988. Taxon-dependent diversification of lifehistory traits and the perception of phylogenetic constraints. Functional Ecology 2: 417-423.

Dirzo R, Raven PH. 2003. Global state of biodiversity and loss. Annual Review of Environment and Resources 28: 137-167.

Eiten G. 1994. Vegetação do Cerrado. In: Pinto MN. (ed.) Cerrado: caracterização, ocupação e perspectivas. Vol. 2. Brasília, Editora UnB p. 17-73.

Eriksson O.2008. Evolution of seed size and biotic seed dispersal in angiosperms: paleoecological and neoecological evidence. International Journal of Plant Sciences 169: 863-870.

Eriksson O, Friis EM, Lofgren P. 2000. Seed size, fruit size, and dispersal systems in angiosperms from the early cretaceous to the late Tertiary. American Naturalist 156: 47-58.

Eriksson O, Jakobsson A. 1999. Recruitment trade-offs and the evolution of dispersal mechanisms in plants. Evolutionary Ecology 13: 411-423.

Felfili JM, Mendonça RC, Munhoz CBR, Fagg CW. 2004. Vegetação e flora da APA Gama e Cabeça de Veado. In: Felfili JM, Santos AAB, Sampaio JC. (eds.) Flora e diretrizes ao plano de manejo da APA Gama e Cabeça de Veado. Brasília, Departamento de Engenharia Florestal, Universidade de Brasília. p. 7-16.

Fenner M. 1985. Seed ecology. New York, Chapman and Hall.

Fleming TH. 1991. Fruiting plant-frugivore mutualism: the evolutionary theater and the ecological play. In: Price PW, Lewinsohn TM, Fernandes GW, Benson WW. (eds.) Plant-animal interactions: evolutionary ecology in tropical and temperate regions. NewYork, J. Wiley and Sons. p.119-144.

Fleming TH, Breitwisch R, Whitesides G. 1987. Patterns of tropical vertebrate frugivore diversity. Annual Review of Ecology and Systematics 18: 91-109.

Fleming TH, Kress WJ. 2013. The ornaments of life: coevolution and conservation in the tropics. Chicago, University of Chicago Press.

Fonseca MS, Silva Júnior MC. 2004. Fitossociologia e similaridade florística entre trechos de Cerrado sentido restrito em interflúvio e em vale no Jardim Botânico de Brasília, DF. Acta Botanica Brasilica 18: 19-29.

Fontes CG, Walter BMT. 2011. Dinâmica do componente arbóreo de uma mata de galeria inundável (Brasília, Distrito Federal) em um período de oito anos. Revista Brasileira de Botânica 34: 145-158.

Forzza RC, Leitman PM, Costa AF, et al. 2015 Lista de Espécies da Flora do Brasil. Jardim Botânico do Rio de Janeiro. <http://floradobrasil.jbrj.gov. br/>. 30 Mar. 2015.

Galetti M, Donatti C, Pires AS, Guimarães Jr PR, Jordano P. 2006. Seed survival and dispersal of an endemic Atlantic forest palm: the combined effects of defaunation and forest fragmentation. Botanical Journal of the Linnean Society 151: 141-149.

Galetti M, Guevara R, Côrtes MC, et al. 2013. Functional extinction of birds drives rapid evolutionary changes in seed size. Science 340: 1086-1090.

GenBank. 2015. NIH genetic sequence database. <http://www.ncbi.nlm.nih. gov/genbank>.30 Mar. 2015. 
Gottsberger G, Silberbauer-Gottsberger I. 2006. Life in the Cerrado: a South American Tropical Seasonal Vegetation. Vol. II. Pollination and Seed Dispersal. Ulm, Reta Verlag.

Haridasan M. 1994. Solos do Distrito Federal. In: Pinto MN. (ed.) Cerrado: caracterização, ocupação e perspectivas. Vol. 2. Brasília, Editora UnB/ SEMATEC. p. 21-344.

Harvey PH, Pagel MD. 1991. The comparative method in evolutionary biology. Vol. 239. Oxford, Oxford University Press.

Hawkins JA. 2006. Using phylogeny to investigate the origins of the Cape flora: The importance of taxonomic, gene and genome sampling strategies. Diversity and Distributions 12: 27-33.

Helmus MR, Keller W, Paterson MJ, Cannon CH, Yan ND, Rusak JA. 2010. Communities contain closely related species during ecosystem disturbance. Ecology Letters 13: 162-174.

Herrera CM. 1989. Seed dispersal by animals: a role in angiosperm diversification? American Naturalist 133: 309-322.

Hoffmann WA. 1996. The effects of fire and cover on seedling establishment in a neotropical savanna. Journal of Ecology 84: 383-393.

Holt RD, Gomulkiewicz R. 2004. Conservation implication of niche conservatism and evolution in heterogeneous environments. In: Ferriere R, Dieckmann U, Couvet DD. (eds.) Evolutionary conservation biology. Cambridge, Cambridge University Press. p. 244-264.

Howe HF, Smallwood J. 1982. Ecology of seeds dispersal. Annual Review of Ecology and Systematics 13: 201-228.

Howe HF, Westley LC. 1997. Ecology of pollination and seed dispersal. In: Crawley MJ. (ed.) Plant Ecology. Oxford, Blackweell Scientific Publication. p. 262-283.

Janzen DH. 1969. Seed-Eaters Versus Seed Size, Number, Toxicity and Dispersal. Evolution 23: 1-27.

Jordano P. 1995. Angiosperm fleshy fruits and seed dispersers: a comparative analysis of adaptation and constraints in plant-animal interactions. American Naturalist 145: 163-191.

Jordano P. 2000. Fruits and frugivory. In: Fenner M. (ed.) Seeds: the ecology of regeneration in plant communities. 2nd. edn. Wallingford, CABI Publ. p. 125-166.

Jordano P, Galetti M, Pizo MA, Silva WR. 2006. Ligando frugivoria e dispersão de sementes à biologia da conservação. In: Rocha CFD. Bergallo HG, Alves MAS, Sluys M. (eds.) Biologia da conservação: essências. São Paulo, Editorial Rima. p. 411-436.

Klink CA, Machado RB. 2005. Conservation of the Brazilian Cerrado. Conservation Biology 19: 707-713.

Knapp S, Kuhn I, Schweiger O, Klotz S. 2008. Challenging urban species diversity: contrasting phylogenetic patterns across plant functional groups in Germany. Ecology Letters 11:, 1054-1064.

Leishman MR, Wright IJ, Moles AT, Westoby M. 2000. The evolutionary ecology of seed size. In: Fenner M. (ed.) Seeds: the ecology of regeneration in plant communities. 2nd. edn. Wallingford, CAB International, p. 31-57.

Levin SA, Muller-Landau HC, Nathan R, CHAVE J. 2003. The ecology and evolution of seed dispersal: a theoretical perspective. Annual Review of Ecology, Evolution, and Systematics 34: 575-604.

Lorts CM, Briggeman T, Sang T. 2008. Evolution of fruit types and seed dispersal: a phylogenetic and ecological snapshot. Journal of Systematics and Evolution 46: 396-404.

Losos JB. 2008. Phylogenetic niche conservatism, phylogenetic signal and the relationship between phylogenetic relatedness and ecological similarity among species. Ecology Letters 11: 995-1003.

Losos JB. 2011. Seeing the forest for the trees: The limitations of phylogenies in comparative biology. American Naturalist 177: 709-727.

May RM, Seger J. 1986. Ideas in ecology. American Scientist 74: 256-267.

McDonald JH. 2014. Handbook of Biological Statistics. 3rd. edn. Baltimore, Sparky House Publishing.

Mendonça RC, Felfili JM, Walter BMT, et al. 2008. Flora vascular do bioma Cerrado: checklist com 12.356 espécies. In: Sano SM, Almeida SP, Ribeiro JF. (eds.) Cerrado: Ecologia e Flora. Vol. 2. Brasília, Embrapa Cerrados/ Embrapa Informação Tecnológica. p. 421-1279.

Metzger JP. 2000. Tree Functional Group Richness and Landscape Structure in a Brazilian Tropical Fragmented. Ecological Applications 10: 1147-1161.

Moles AT, Ackerly DD, Webb CO, et al. 2005. Factors that shape seed mass evolution. Proceedings of the National Academy of Sciences of the United States of America 102: 10540-10544.
Moles AT, Falster DS, Leishman MR, Westoby M. 2004. Small-seeded species produce more seeds per square metre of canopy per year, but not per individual per lifetime. Journal of Ecology 92: 384-396.

Moles AT, Westoby M. 2006. Seed size and plant strategy across the whole life cycle. Oikos 113: 91-105.

Mouquet N, Devictor V, Meynard CN, et al. 2012. Ecophylogenetics: advances and perspectives. Biological Reviews: 87: 769-785.

Munhoz CBR, Felfili JM. 2007. Reproductive phenology of an herbaceoussubshrub layer of a Savannah (Campo Sujo) in the Cerrado Biosphere Reserve I, Brazil. Brazilian Journal of Biology 67: 299-307.

Münkemüller T, Lavergne S, Bzeznik B, et al. 2012. How to measure and test phylogenetic signal. Methods in Ecology and Evolution: 3: 743-756.

Myers N, Mittermeier RA, Mittermeier CG, Fonseca GA, Kent J. 2000. Biodiversity hotspots for conservation priorities. Nature 403: 853-858.

Okubo A, Levin SA. 1989. A theoretical framework for data analysis of wind dispersal of seeds and pollen. Ecology 70: 329-338.

Pagel M. 1999. Inferring the historical patterns of biological evolution. Nature 401: 877-884

Palermo AC, Miranda HS. 2012. Effect of fire on the fruit production of Qualea parviflora Mart. (Vochysiaceae) in the Cerrado. Revista Árvore 36: 685-693.

Pennington RT, Richardson JE, Lavin M. 2006a. Insights into the historical construction of species-rich biomes from dated plant phylogenies, neutral ecological theory and phylogenetic community structure. New Phytologist 172: 605-616.

Pennington RT, Lewis GP, Ratter JA. 2006b. An overview of the plant diversity, biogeography and conservation of neotropical savannas and seasonally dry forests. In: Pennington RT, Lewis GP, Ratter JA. (eds.) Neotropical Savannas and Seasonally Dry Forests: Plant Diversity, Biogeography, and Conservation. Boca Raton, CRC Press. p. 1-29.

Pereira BAS, Silva MA, Mendonça RC. 1993. Reserva Ecológica do IBGE, Brasília (DF): lista das plantas vasculares. Rio de Janeiro, IBGE Divisão de Geociências do Distrito Federal.

Pijl L. 1982. Principles of Dispersal in Higher Plants. New York, Springer-Verlag Berlin Heidelberg.

Pinheiro F, Ribeiro JF. 2001. Síndromes de dispersão de sementes em Matas de Galeria do Distrito Federal. In: Ribeiro JF, Fonseca CEL, Sousa-Silva JC. (eds.) Cerrado: caracterização e recuperação de Matas de Galeria. Planaltina, Embrapa Cerrados.

Proença CEB, Munhoz CBR, Jorge CL, Nóbrega MGG. 2001. Listagem e nível de proteção das espécies de fanerógamas do Distrito Federal, Brasil. Flora do Distrito Federal, Brasi 1: 87-359.

Ramos PCM. 1995. Vegetation communites and soils in the National Park of Brasília. Edinburgh, University of Edinburgh.

Ratter JA, Ribeiro JF, Bridgewater S. 1997. The Brazilian cerrado vegetation and threats to its biodiversity. Annals of Botany 80: 223-230.

Reatto A, Correia JR, Spera ST. 2008. Solos do bioma Cerrado. In: Sano SM, Almeida SP, Ribeiro JF. (eds.) Cerrado: Ecologia e Flora. Vol. 1. Brasília, Embrapa Cerrados/Embrapa Informação Tecnológica. p 109-149.

Revell LJ. 2012. Phytools: an R package for phylogenetic comparative biology (and other things). Methods in Ecology and Evolution 3: 217-223

Revell LJ, Harmon LJ, Collar DC. 2008. Phylogenetic signal, evolutionary process, and rate. Systematic Biology 57: 591-601.

Ribeiro JF, Walter BMT. 2008. As principais fitofisionomias do bioma Cerrado. Pp. 151-212. In: Sano SM, Almeida SP, Ribeiro JF (Eds.). Cerrado: Ecologia e Flora. Vol. 1. Brasília, Embrapa Cerrados/Embrapa Informação Tecnológica.

Sano EE. 2013. Mapa de uso e cobertura de terras do Distrito Federal (shapefile). Brasília, Embrapa Cerrados.

Sano EE, Rosa R, Brito JL, Ferreira Jr LG. 2008. Mapeamento semidetalhado do uso da terra do Bioma Cerrado. Pesquisa Agropecuaria Brasileira 43: 153-156.

Silva FD, Assad ED, Evangelista BA. 2008. Caracterização climática do bioma Cerrado. In: Sano SM, Almeida SP, Ribeiro JF. (eds.) Cerrado: Ecologia e Flora. Vol. 1. Brasília, Embrapa Cerrados/Embrapa Informação Tecnológica. p. $71-88$.

Simon MF, Grether R, Queiroz LP, Skema C, Pennington RT, Hughes CE. 2009. Recent assembly of the Cerrado, a neotropical plant diversity hotspot, by in situ evolution of adaptations to fire. Proceedings of the National Academy of Sciences 106: 20359-20364.

Spujt RW. 1994. A systematic treatment of fruit types. Memoirs of the New York Botanical Garden 70: 1-181. 


\section{Marcelo Kuhlmann and José Felipe Ribeiro}

Thomson FJ, Moles AT, Auld TD, Ramp D, Ren S, Kingsford RT. 2010. Chasing the unknown: predicting seed dispersal mechanisms from plant traits. Journal of Ecology 98: 1310-1318

Tiffney BH. 1984. Seed size, dispersal syndromes, and the rise of the angiosperms: evidence and hypothesis. Annals of the Missouri Botanical Garden: 551-576.

Tiffney BH. 2004. Vertebrate dispersal of seed plants through time. Annual Review of Ecology, Evolution, and Systematics 1-29.

Tiffney BH, Mazer SJ. 1995. Angiosperm growth habit, dispersal and diversification reconsidered. Evol. Ecol. 9: 93-117.

Vargas P, Heleno R, Traveset A, Nogales M. 2012. Colonization of the Galápagos Islands by plants with no specific syndromes for long-distance dispersal: a new perspective. Ecography 35: 33-43.

Walter BMT. 2001. A pesquisa botânica na vegetação do Distrito Federal, Brasil. In: Cavalcanti TB, Ramos AE. (eds.) Flora do Distrito Federal, Brasil. Vol. I. Brasília, Embrapa Recursos Genéticos e Biotecnologia.
Westoby M, Leishman M, Lord J. 1996. Comparative ecology of seed size and dispersal. Philosophical Transactions of the Royal Society of London Series B-Biological Sciences 351: 1309-1318.

Wiens JJ, Ackerly DD, Allen AP, et al. 2010. Niche conservatism as an emerging principle in ecology and conservation biology. Ecology Letters 13: 1310-1324.

Wiesbauer MB, Giehl ELH, Jarenkow JA. 2008. Padrões morfológicos de diásporos de árvores e arvoretas zoocóricas no Parque Estadual de Itapuã, RS, Brasil. Acta Botanica Brasilica 22: 425-435.

Willson MF. 1993. Dispersal mode, seed shadows, and colonization patterns. Vegetation 107/108: 261-280.

Willson MF, Rice BL, Westoby M. 1990. Seed dispersal spectra, a comparison of temperate plant communities. Journal of Vegetation Science 1: 547-562.

Zaidan LB, Carreira RC. 2008. Seed germination in Cerrado species. Brazilian Journal of Plant Physiology 20: 167-181. 